\title{
25. DISTRIBUTION AND CHARACTER OF PALE GREEN LAMINAE IN SEDIMENT FROM LORD HOWE RISE: A PROBABLE LATE NEOGENE AND QUATERNARY TEPHROSTRATIGRAPHIC RECORD ${ }^{1}$
}

\author{
James V. Gardner, U.S. Geological Survey \\ Campbell S. Nelson, University of Waikato \\ and \\ Paul A. Baker, Duke University ${ }^{2}$
}

\begin{abstract}
Pale green laminae $<2 \mathrm{~mm}$ thick are common features of the Neogene and Quaternary sediment of Lord Howe Rise. We believe these laminae represent diagenetically altered volcanic ash layers from regional volcanic events. Although no consistent high abundances of volcanic glass are found within the laminae, the volcanic origin of the laminae is suggested by (1) similar temporal distribution of the laminae and the distribution of volcanic ash layers elsewhere in the southwest Pacific; (2) the high abundances of authigenic smectite in the laminae; and (3) the common occurrence of iron sulfides in proximity to most of the laminae. The resulting tephrostratigraphy is considerably more complex and detailed than was previously known.
\end{abstract}

\section{INTRODUCTION}

During the shipboard descriptions of the sediment recovered from Lord Howe Rise on Deep Sea Drilling Project (DSDP) Leg 90, we observed numerous, thin, pale green laminations (PGLs) that persist through long intervals of the cores. We tabulated the frequency of occurrence of these PGLs and have attempted to identify their origin. Our purpose in this paper is to (1) describe the PGLs, (2) report on a series of analyses of these laminae, (3) discuss the possibilities for their origin, and (4) argue that the PGLs are bentonites, a term used here in a general way for altered tephra layers. We present data from five sites (Sites 588, 590, 591, 592, and 593) (Fig. 1) where we recovered virtually complete sequences of the upper Neogene and Quaternary.

\section{DESCRIPTION AND OCCURRENCE OF THE PALE GREEN LAMINAE}

The general lithofacies of sediment from all the sites is foraminifer-bearing nannofossil ooze or nannofossil ooze to chalk. Fragments of siliceous microfossils, when they occur, are only in trace $(<1 \%)$ amounts. Rare, clear volcanic glass, pyrite, quartz, and feldspars were observed in smear slides of some samples. The PGLs are typically 0.5 to about $2 \mathrm{~mm}$ thick; a few are about $5 \mathrm{~mm}$ thick. The laminae occur as an isolated or as a composite sets of laminae. They range in color from hues of pale green (5G) and yellow green (5GY) to greenish yellow (10Y), appearing as more or less distinct layers within the otherwise white (N9) to light gray (N7) or

\footnotetext{
${ }^{1}$ Kennett, J. P., von der Borch, C. C., et al., Init. Repts. DSDP, 90: Washington (U.S. Govt, Printing Office).

2 Address: (Gardner) U.S. Geological Survey, Menlo Park, CA 94025; (Nelson) University of Waikato, Hamilton, New Zealand; (Baker) Duke University, Durham, NC 27708.
}

light greenish gray $(5 \mathrm{G} 8 / 1)$ bioturbated and mottled pelagic facies. The PGLs are not burrows, and all are horizontal or nearly so. There were no observations of a PGL cross-cutting a trace fossil or other sedimentary structures that might suggest a secondary origin for the laminae. The PGLs commonly occur a few centimeters above a lens or pocket of iron sulfides.

Attempts to photograph the PGLs were not very successful because of the subtle differences between the green hues of the dominant carbonate facies and the PGLs. However, a few of the more obvious PGLs did photograph well enough to demonstrate their general appearance (Fig. 2).

Figure 3 is a plot of the occurrence of volcanic glass identified in routine shipboard smear slides and the number of PGLs per core for each site. The counts were made on each section of each core as it was described and are not necessarily represented on the core summaries at the end of each site chapter (this volume). The smear-slide data are compilations of analyses by the six shipboard sedimentologists. The smear-slide data are semiquantitative, with abundance ranges of trace $(T)=<1 \%$, rare $(\mathrm{R})=1-5 \%$, common $(\mathrm{C})=5-25 \%$, abundant (A) $=25-75 \%$, and dominant (D) $=>75 \%$. Figure 4 is a plot of the number of PGLs observed versus age. To construct this plot, we used the detailed nannofossil stratigraphy and nannofossil zonal ages (site chapters, this volume) and interpolated the ages for the top and bottom of each recovered core assuming a constant sedimentation rate between each of the consecutive nannofossil datums (Table 1). The age of the top and bottom of each core was calculated using Equations 1 and 2, respectively.

$$
A_{\mathrm{T}}=\frac{\left(C_{\mathrm{T}}-N N Z\right)}{N N R}+N N A
$$




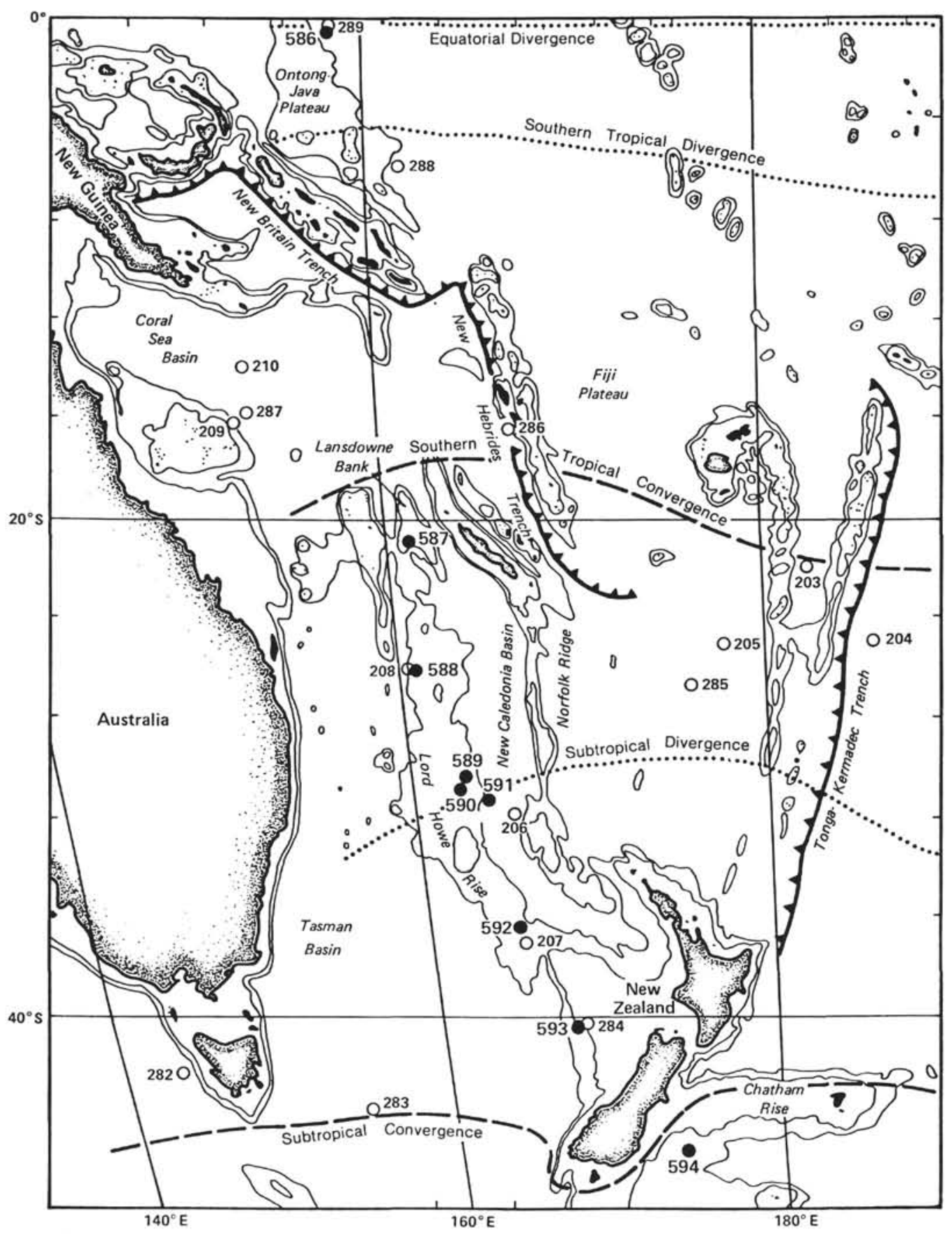

Figure 1. Location map of Lord Howe Rise, locations of Leg 90 sites, and the generalized bathymetric and surface oceanographic features of the region.

$$
A_{\mathrm{B}}=\frac{\left(C_{\mathrm{B}}-N N Z\right)}{N N R}+N N A
$$

where

$$
\begin{aligned}
& A_{\mathrm{T}}=\text { age at the top of a core, } \\
& A_{\mathrm{B}}=\text { age at the bottom of a core, } \\
& N N Z=\text { sub-bottom depth of top of an NN zone, } \\
& N N A=\text { age of top of an NN zone, } \\
& N N R=\text { accumulation rate of the NN zone, } \\
& C_{\mathrm{T}}=\text { sub-bottom depth of core top, and } \\
& C_{\mathrm{B}}=\text { sub-bottom depth of core bottom. }
\end{aligned}
$$

Sites in the central part of Lord Howe Rise (Sites 588, 590 , and 591) have a higher abundance of PGLs in the middle and lower upper Miocene sections relative to the sites farther to the south (Sites 592 and 593). Conversely, southern sites (Sites 592 and 593) have a higher abundance of PGLs in the Quaternary section than the central sites (Sites 588 and 590).

\section{POSSIBLE ORIGINS OF THE PALE GREEN LAMINAE}

We believe the PGLs are the products of discrete ash falls. However, as will be seen, our evidence is equivo- 



Figure 2. A. Sample 588B-22-4, 83-100 cm ( $205 \mathrm{~m}$ sub-bottom) showing a pale green lamina (solid triangles) and pockets of iron sulfides (solid circles). Sample 599C-16-3, 89-112 cm (453 m sub-bottom) showing several PGLs (solid triangles). Notice several of the zones of PGLs are composite laminae. The circular feature at 89 to $92 \mathrm{~cm}$ is a Planolites-type burrow that has itself been burrowed.

cal, so first we will discuss briefly some other possibilities for their origin.

Dean et al. $(1977 ; 1981)$ and Arthur et al. (in press) discussed Jurassic to Holocene cycles of oxidation, reduction, and dissolution in deep-sea sediment. The cycles discussed by them have roughly equal hemicycles; that is, the reduced section is about the same length (in time or stratigraphic thickness) as the oxidized hemicycle. The same relationship follows for dissolution cycles
(Gardner, 1975). In contrast to these sedimentary cycles, the PGLs do not represent a roughly equal segment of stratigraphic thickness with the surrounding facies; the PGLs are generally $<2 \mathrm{~mm}$ thick but the surrounding facies is often $>50 \mathrm{~cm}$ thick. There does not appear to be any difference in preservation of calcareous microfossils between the two facies, nor does there appear to be any difference in grain size. These two observations preclude dissolution cycles and winnowing events. 

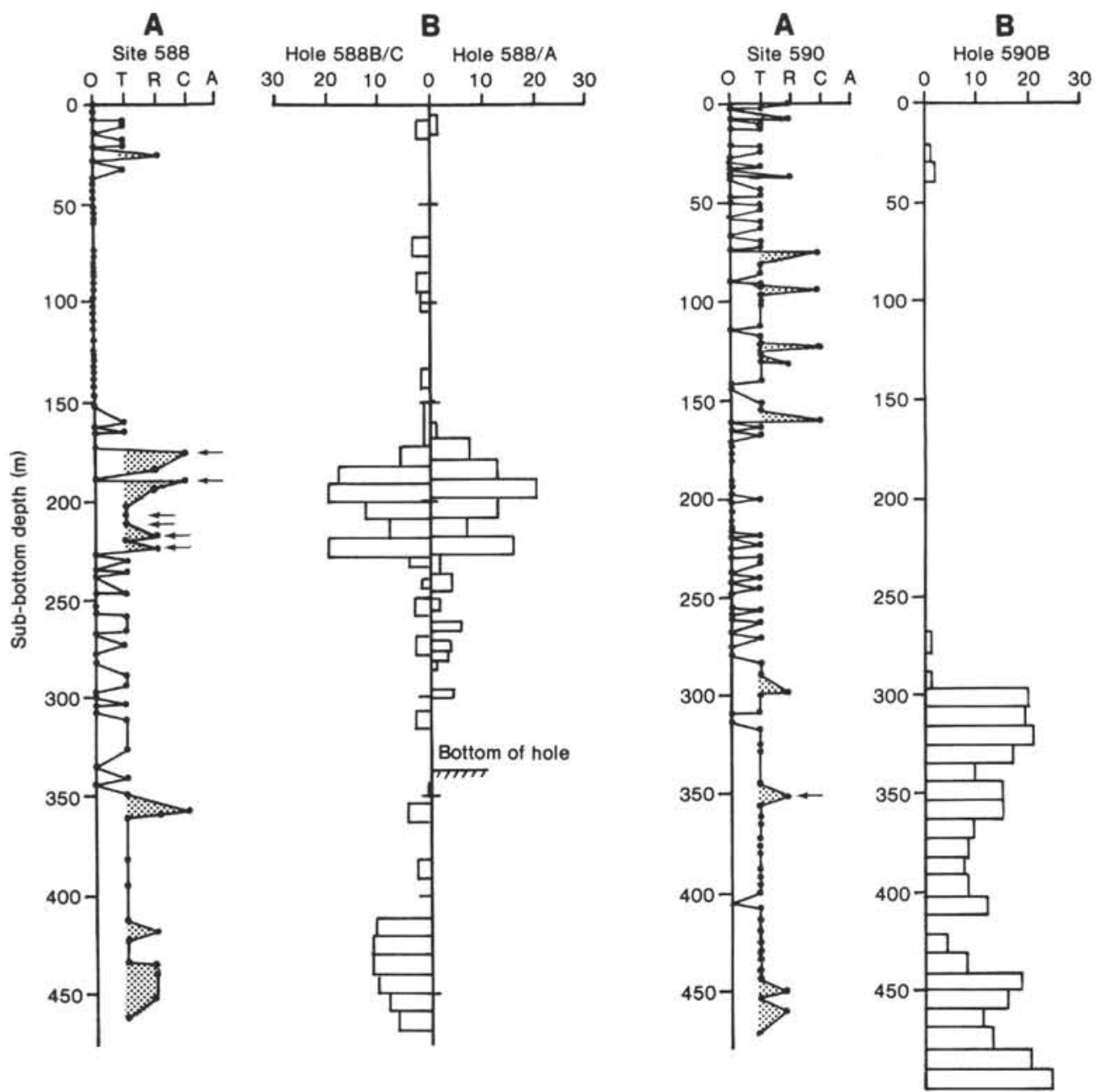

Figure 3. The distribution of pale green laminae (PGLs) and volcanic glass shards in smear slides from DSDP Sites 590, 591, 592, and 593. For each site, column A indicates amounts of volcanic glass in smear slides, column B the number of PGLs per core. Smear-slide estimates are T (trace) $=<1 \%, \mathrm{R}$ (rare) $=1-5 \%$, $\mathrm{C}$ (common) $=5-25 \%, \mathrm{~A}$ (abundant) $=25-75 \%$, and $\mathrm{D}$ (dominant) $=>75 \%$. The distribution of PGLs is number of PGLs per core, scaled to the sub-bottom depth interval of each core (see specific site chapters for intervals of recovery). Arrows indicate the occurrence of observed discrete ash layers.

Conceivably, the PGLs could have been produced by local differences in the oxidation state of the sediment. This is discounted by the observation that the entire sediment section, from approximately 1 to $2 \mathrm{~m}$ sub-bottom to the bottom of the holes, is anoxic and mildly sulfatereducing, as is demonstrated by the common presence of pyrite and iron sulfide staining throughout the sections as well as by lower-than-seawater concentrations of sulfate in pore water at every site (Baker, this volume). Another possibility is that the pale green laminae represent brief episodes of dilution by some exotic (other than tephra) material. Again, smear-slide and scanning electron microscopy (SEM) observations and X-ray diffraction (XRD) analyses did not reveal any notable differences between PGLs and surrounding sediment, other than in clay mineralogy.

In light of the preceding discussion of the general characteristics of the lithofacies, we have discounted cyclic sedimentation and cyclic diagenesis as the origin of the pale green laminae.

\section{EVIDENCE SUPPORTING A TEPHRA ORIGIN}

Circumstantial evidence led us to propose tephra as the origin of the PGLs. The temporal distribution of PGLs and the previously published record of discrete volcanic ash layers in the southwest Pacific (Fig. 5) show striking similarities. The occurrence of volcanism in the southwest Pacific shows a pronounced middle to early late Miocene high followed by relative quiescence through the Pliocene and renewed volcanism in the Quaternary. This distribution is found throughout the margin of the Pacific (Kennett et al., 1977), but is especially strong in the southwest Pacific (Kennett and Thunell, 1975). However, several problems arise when attempting to compile data on ash layers in deep-sea sediment. The occurrence of ash initially depends on the intensity of the eruption and the climatic conditions, especially the direction and strength of the winds. An ash bed, once deposited, may be significantly modified or destroyed by reworking by currents, slumping, bioturbation, diagenesis, and, with 

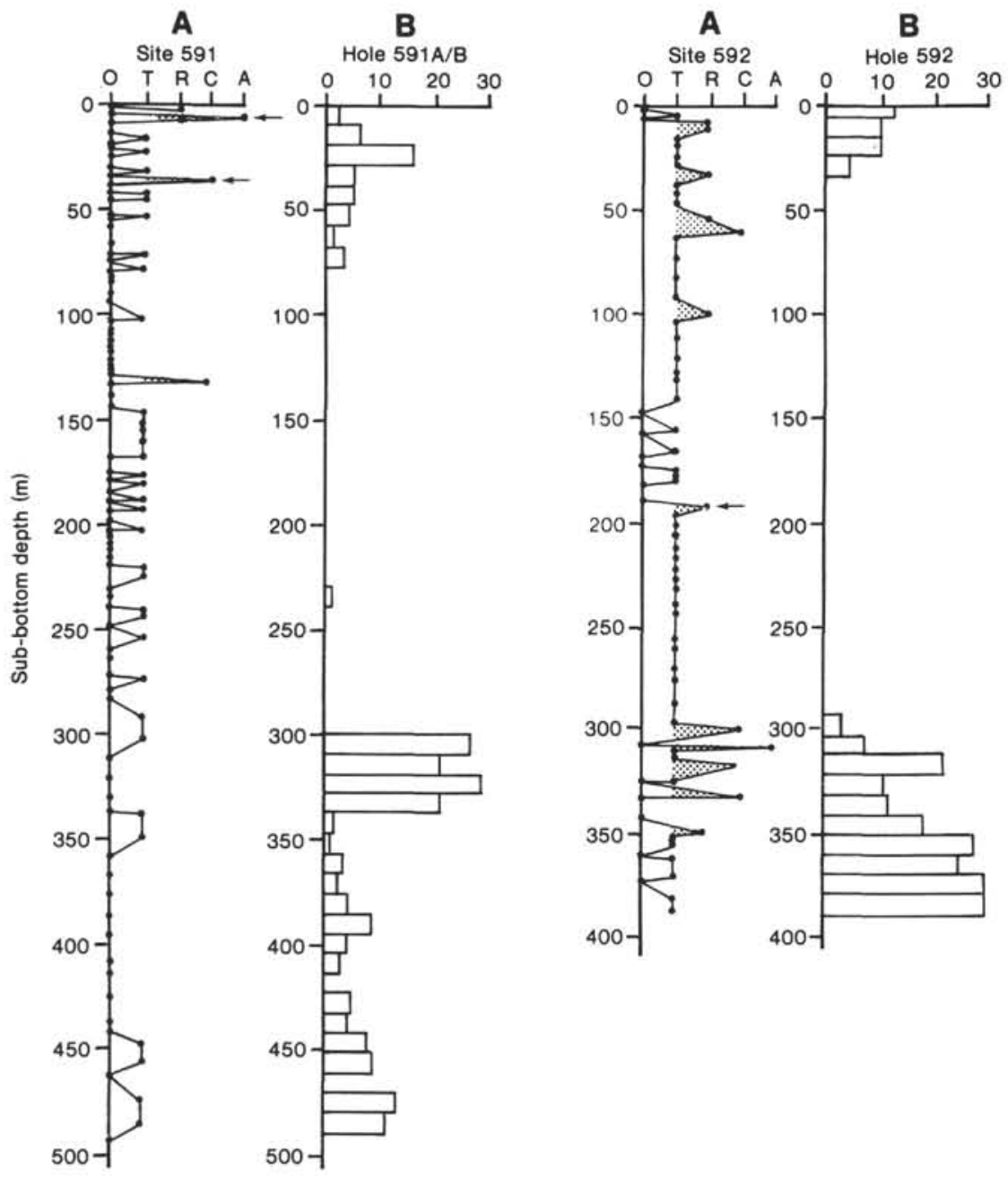

Figure 3. (Continued).

rotary drilling, by the coring process itself. An ash can be preserved as a discrete bed, a pod, or dispersed shards. Shards generally cannot be detected megascopically and require detailed analyses of channel samples to produce frequency data on volcanic activity (Ledbetter, 1982).

Hein et al. (1978) discussed the inconsistent counting techniques used by different workers and the effects this inconsistency has on the interpretation of ash layers in DSDP cores. They also emphasized how diagenesis can obscure the tephrostratigraphy by alteration of volcanic ash beds to bentonite. Many bentonite beds in North Pacific DSDP sites are developed in the older (pre-Pliocene) deposits of diatomaceous muds and are largely indistinguishable from them except by mineralogical analysis (Hein et al., 1978).

All the Lord Howe Rise holes discussed here show a pattern of PGLs that is similar to the distribution of tephra in other Pacific Ocean sites; the highest abundances of PGLs occur in the middle and lower upper

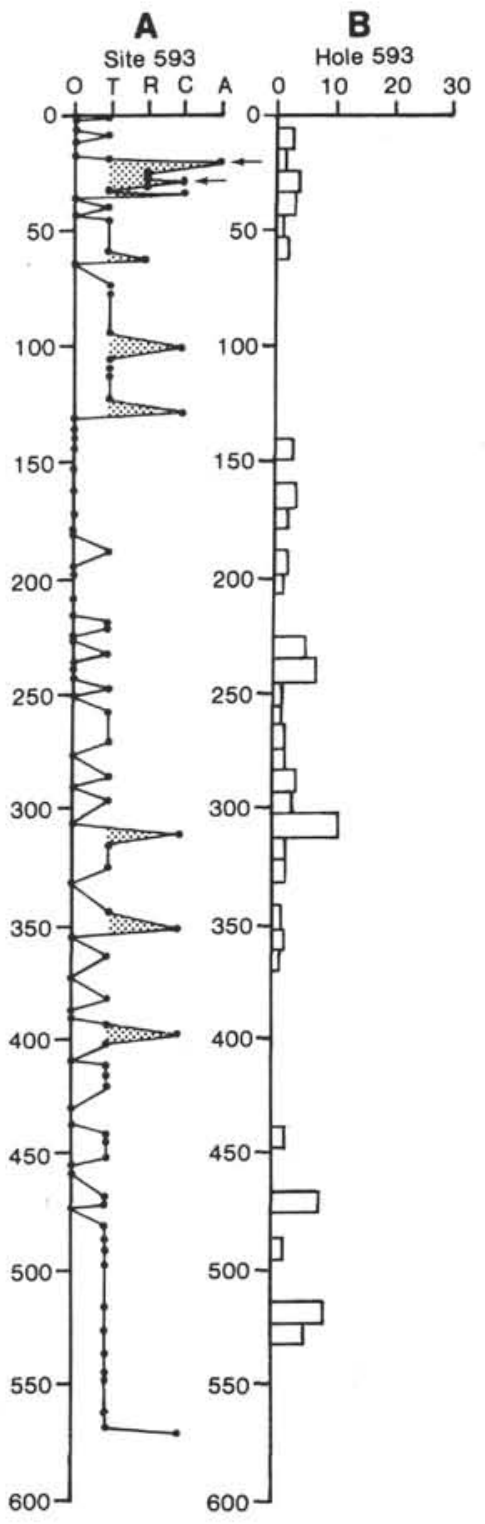

Miocene intervals, generally followed by few PGLs in the Pliocene intervals, then by numerous PGLs in the Quaternary sections. The correspondence between abundances of volcanic glass in smear slides greater than trace amounts $(<1 \%)$ and the abundances of PGLs (Fig. 3) is good only at Site 588 and fair at Site 592. However, at all sites where the abundance estimates of volcanic glass indicates the presence of greater than trace amounts, there are numerous PGLs.

Volcanic glass and biogenic silica are scarce to absent from intervals with high counts of PGLs. Subtropicalto temperate-latitude deep-sea sediment deposited well above the lysocline should have an appreciable component of diatoms and radiolarians. The relatively fast accumulation rates of the sediment at Leg 90 sites (10 to $>50 \mathrm{~m} / \mathrm{m}$.y.) suggest high productivity, which in turn implies that biosiliceous components must have been supplied to the sediment (Diester-Haass and Schrader, 1979; Schuette and Schrader, 1981; de Vries and Schrader, 1981). 



\begin{tabular}{|l|l|l|l|l|l|l}
\hline Quat. & $\begin{array}{l}\text { late } \\
\text { Plio. }\end{array}$ & $\begin{array}{l}\text { early } \\
\text { Plio. }\end{array}$ & late Miocene & middle Miocene & early Miocene & late Oligocene \\
\hline
\end{tabular}

Figure 4. The number of pale green laminae (PGLs) per million years for DSDP Sites 588, 590, 591, 592, and 593. The ages of each recovered nannofossil zone (Table 1) was used to extrapolate the ages of the top and bottom ages of each core. The duration represented by each core was used to normalize the number of PGLs per m.y. 
Table 1. Ages (m.y.) of tops of nannofossil zones used to interpolate age in Figure 2 (from Introduction, this volume).

\begin{tabular}{ccrc}
\hline $\begin{array}{c}\text { Nannofossil } \\
\text { zone }\end{array}$ & Age & $\begin{array}{c}\text { Nannofossil } \\
\text { zone }\end{array}$ & Age \\
\hline NN21 & 0.00 & NN7 & 12.20 \\
20 & 0.20 & 6 & 13.00 \\
19 & 0.55 & 5 & 15.00 \\
18 & 1.90 & 4 & 17.00 \\
17 & 2.30 & 3 & 17.80 \\
16 & 2.40 & 2 & 19.00 \\
15 & 3.45 & 1 & 20.50 \\
14 & 3.65 & NP25 & 23.6 \\
13 & 4.10 & 24 & 26.0 \\
12 & 4.60 & 23 & 32.0 \\
$11 b$ & 5.20 & 22 & 34.0 \\
$11 \mathrm{a}$ & 6.25 & 21 & 36.5 \\
10 & 9.50 & 20 & 37.5 \\
9 & 11.00 & 19 & 41.0 \\
8 & 12.00 & & \\
\hline
\end{tabular}

Insoluble residues of $25-50 \mathrm{~cm}^{3}$ of sediment have, if any, only traces of biosiliceous material in them (see site chapters, this volume). Site 591 is an exception; it contains biogenic silica in trace amounts throughout the section. Site 591 is located in the deepest waters of all the Leg 90 sites, and, as will be discussed later, this may explain the presence of biosiliceous components. Consequently, we believe there must have been severe postdepositional dissolution of the biogenic silica. Analyses of pore waters indicate consistently very low concentrations of dissolved silica at all sites (except Site 591) in sediment younger than late Miocene, which reflects the low content of solid biogenic silica. The low concentrations of dissolved silica promote the congruent dissolution of volcanic glass. Alternately, volcanic glass can devitrify to palagonite (Peterson and Griffin, 1964) or incongruently dissolve to yield palygorskite (Hathaway and Sachs, 1965; Siever and Kastner, 1967), smectite (Peterson and Griffin, 1964; Nayudu, 1964; von Rad and Rösch, 1972), and zeolites (Arrhenius, 1963; Bonatti, 1972; Stonecipher, 1974).

To investigate further the possibility that the PGLs are bentonites, several PGLs were sampled for clay mineralogy by XRD analyses. In addition, samples were taken in sections where no PGLs occur. Approximately $10 \mathrm{~cm}^{3}$ was collected for each sample. Standard techniques were used to prepare the samples (Hein et al., 1976), and the weighted peak area techniques of Biscaye (1965) were used to analyze the diffractograms. The results (Table 2) clearly show that the dominant clay mineral in almost all PGL samples is smectite (Fig. 6). Several of the PGL samples analyzed have no clays present,
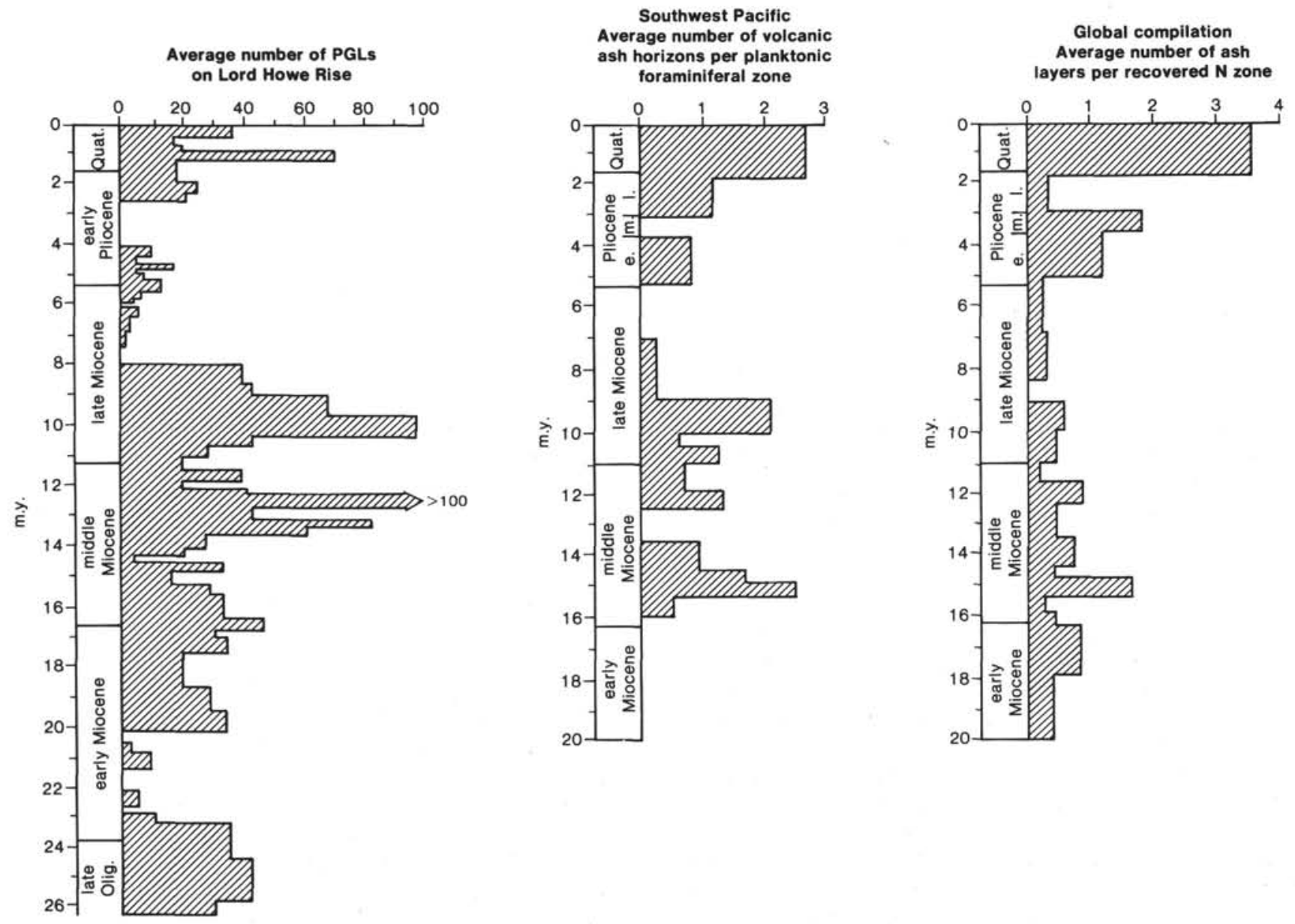

Figure 5. The distribution of PGLs on Lord Howe Rise and the distribution of discrete volcanic ash layers from the southwest Pacific and the global distribution of volcanic ash (after Kennett et al., 1977). 
Table 2. Results of XRD analyses. Clay mineralogy is the relative percentages of the $\langle 2-\mu \mathrm{m}$ fraction where $\mathrm{sm}=\mathrm{smec}$ tite, ill $=$ illite, and ch $+\mathrm{k}=$ chlorite plus kaolinite.

\begin{tabular}{|c|c|c|c|c|c|}
\hline \multirow{2}{*}{$\begin{array}{l}\text { Sample } \\
\text { (interval in } \mathrm{cm} \text { ) }\end{array}$} & \multirow{2}{*}{$\begin{array}{l}\text { Sub-bottom } \\
\text { depth } \\
\text { (m) }\end{array}$} & \multirow[b]{2}{*}{ Age } & \multicolumn{3}{|c|}{ Clay mineralogy } \\
\hline & & & $\mathrm{sm}$ & ill & $\mathrm{ch}+\mathrm{k}$ \\
\hline \multicolumn{6}{|c|}{ Pale green laminae } \\
\hline $591 \mathrm{~A}-3-3,26$ & 22.06 & Quat. (NN19) & 50 & 16 & 33 \\
\hline $591 \mathrm{~A}-3-3,68$ & 22.48 & Quat. (NN19) & 76 & 6 & 17 \\
\hline $591 \mathrm{~A}-3-3,86$ & 22.66 & Quat. (NN19) & 50 & 19 & 32 \\
\hline 591A-3-3, 92 & 22.72 & Quat. (NN19) & 48 & 18 & 34 \\
\hline $591 \mathrm{~A}-3-3,104$ & 22.84 & Quat. (NN19) & 46 & 20 & 34 \\
\hline $591 \mathrm{~A}-3-4,5$ & 23.35 & Quat. (NN19) & 25 & 23 & 52 \\
\hline $591 \mathrm{~A}-3-4,15$ & 23.45 & Quat. (NN19) & 62 & 12 & 26 \\
\hline $591 A-3-5,20$ & 25.00 & Quat. (NN19) & 63 & 8 & 20 \\
\hline 591A-3-5, 27 & 25.07 & Quat. (NN19) & 54 & 22 & 24 \\
\hline $591 \mathrm{~A}-3-6,50$ & 26.80 & Quat. (NN19) & 51 & 18 & 30 \\
\hline $591-19-2,110$ & 167.40 & Plio. (NN14) & 57 & 20 & 23 \\
\hline $591-19-4,40$ & 169.70 & Plio. (NN14) & 55 & 20 & 25 \\
\hline $591-19-5,110$ & 171.90 & Plio. (NN14) & 69 & 12 & 19 \\
\hline \multicolumn{6}{|c|}{ Nonpale green laminae } \\
\hline $591-15-1,40$ & 128.00 & Plio. (NN15) & & - & \\
\hline $591-15-2,70$ & 129.80 & Plio. (NN15) & & - & \\
\hline $591-15-3,110$ & 131.70 & Plio. (NN15) & & - & \\
\hline $591-15-5,40$ & 134.00 & Plio. (NN15) & & - & \\
\hline $591-15-6,40$ & 135.50 & Plio. (NN15) & & - & \\
\hline $591-16-1,110$ & 138.00 & Plio. (NN15) & & - & \\
\hline $591-16-3,40$ & 140.30 & Plio. (NN15) & & - & \\
\hline $591-16-6,40$ & 144.80 & Plio. (NN15) & 67 & 11 & 23 \\
\hline $591-17-3,40$ & 149.60 & Plio. (NN15) & 64 & 15 & 21 \\
\hline $591-17-4,110$ & 151.80 & Plio. (NN15) & & - & \\
\hline $591-17-6,40$ & 154.10 & Plio. (NN15) & & - & \\
\hline $591-18-4,40$ & 160.40 & Plio. (NN15) & & - & \\
\hline $591-18-5,110^{\mathrm{a}}$ & 162.60 & Plio. (NN15) & 60 & 14 & 24 \\
\hline $591-20-1,40$ & 174.70 & Plio. (NN14) & & - & \\
\hline $591-20-2,110$ & 176.90 & Plio. (NN14) & & - & \\
\hline $591-20-4,40^{\mathrm{a}}$ & 179.20 & Plio. (NN14) & 60 & 17 & 23 \\
\hline $591-20-5,110$ & 181.40 & Plio. (NN14) & & - & \\
\hline $591-20-6,110$ & 182.90 & Plio. (NN14) & & - & \\
\hline
\end{tabular}

Note: $-=$ no clays present.

${ }^{a}$ Samples within $15 \mathrm{~cm}$ of a zone of pale green laminae.

but those samples are either older than 5 m.y. and occur deeper than $300 \mathrm{~m}$ sub-bottom, or contain so little claysized material that the analyses are questionable. Scanning electron micrographs of PGLs (Fig. 7) clearly show the presence of authigenic smectite as highly wrinkled or honeycomb-like flakes and sheets (Wilson and Pittman, 1977). The abundances of smectite in PGL samples (avg. $=55.2 \%$; S.D. $=11.6 \%$ ) are well within the range that Hein and Scholl (1978) used to identify bentonites. The lack of smectite in the pre-Pliocene PGL samples suggests that diagenetic processes have broken down the clays and remobilized the elements. However, the PGLs remain visible in the pre-Pliocene sediment. Interestingly, Hein and Scholl (1978) did not observe smectites in volcanogenic sediment any younger than Miocene in sediment from the Bering Sea.

These results encouraged additional, more detailed research into the clay mineralogy. Eight samples of sediment containing PGLs from Sites 588 and 591 were dissolved in 4M acetic acid, known not to alter clay minerals (Carroll and Starkey, 1971). The residue was washed several times with distilled water and then wet-sieved through a $63-\mu \mathrm{m}$ screen. The $<63-\mu \mathrm{m}$ fraction was centrifuged and a slurry was drawn off, dropped onto a

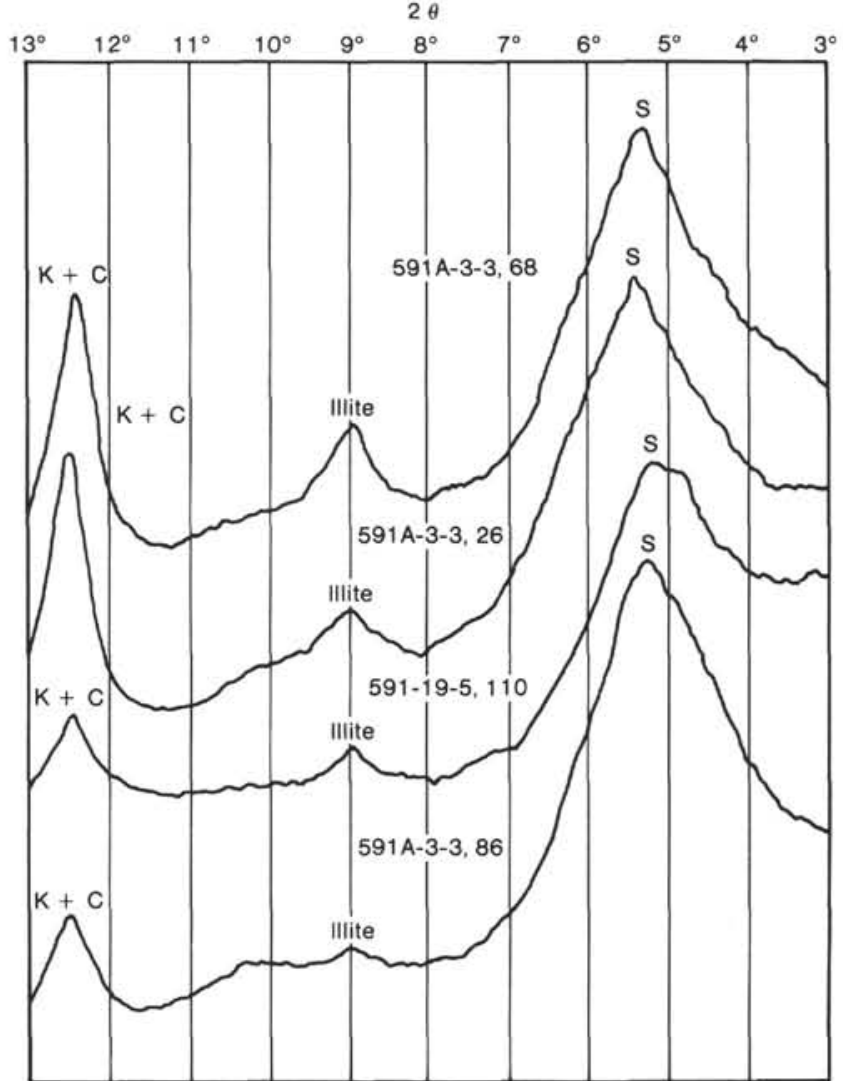

Figure 6. X-ray diffractograms of the glycolated $<2-\mu \mathrm{m}$ fraction of sediment comprising a pale green laminae. $\mathrm{S}=$ smectite, $\mathrm{Ill}=$ illite, and $\mathrm{K}+\mathrm{C}=$ kaolinite plus chlorite.

glass slide, and rapidly dried with a low-intensity infrared lamp for about $20 \mathrm{~min}$. Three X-ray runs were performed on aliquots of each sample: (1) an untreated sample; (2) following ethylene glycolation for $12 \mathrm{hr}$. to test for smectite; and (3) after heating to $500^{\circ} \mathrm{C}$ for $1 \mathrm{hr}$. to test for dehydration of smectite and the nature of any chlorite components (Hume and Nelson, 1982). In addition, suspensions were boiled in $10 \% \mathrm{HCl}$ for $5 \mathrm{~min}$. to distinguish between kaolinite and chlorite (Brindley, 1972), then saturated in $1 N \mathrm{KOH}$ for $15 \mathrm{hr}$. and heated in $1 \mathrm{~N} \mathrm{KOH}$ at $90^{\circ} \mathrm{C}$ for $1 \mathrm{hr}$. to note the degree of contraction of smectite through $\mathrm{K}^{+}$uptake, which can indicate the general nature of the parent material (Weaver, 1958).

The results of these treatments show that the clay mineralogy of the PGLs is similar for all samples analyzed (Fig. 8). A broad, major (001) reflection between 14.3 and $16.0 \AA$ expanded to $15.5-17.7 \AA$ upon glycolation and collapsed to $9.8 \AA$ after heating. These are characteristics of dominant smectite clays in the samples. The (001) smectite peak showed only partial contraction to $12-13 \AA$ after the KOH treatments, which supports the derivation of the smectite from materials with a low inherited charge, such as volcanic ash, rather than from the argillization of sheet silicates such as muscovite or biotite (Weaver, 1958; Hume and Nelson, 1982). The (060) spacing of the smectites is from 1.49 to $1.52 \AA$, which suggests that their octahedral layer is of a dioctahedral 
A

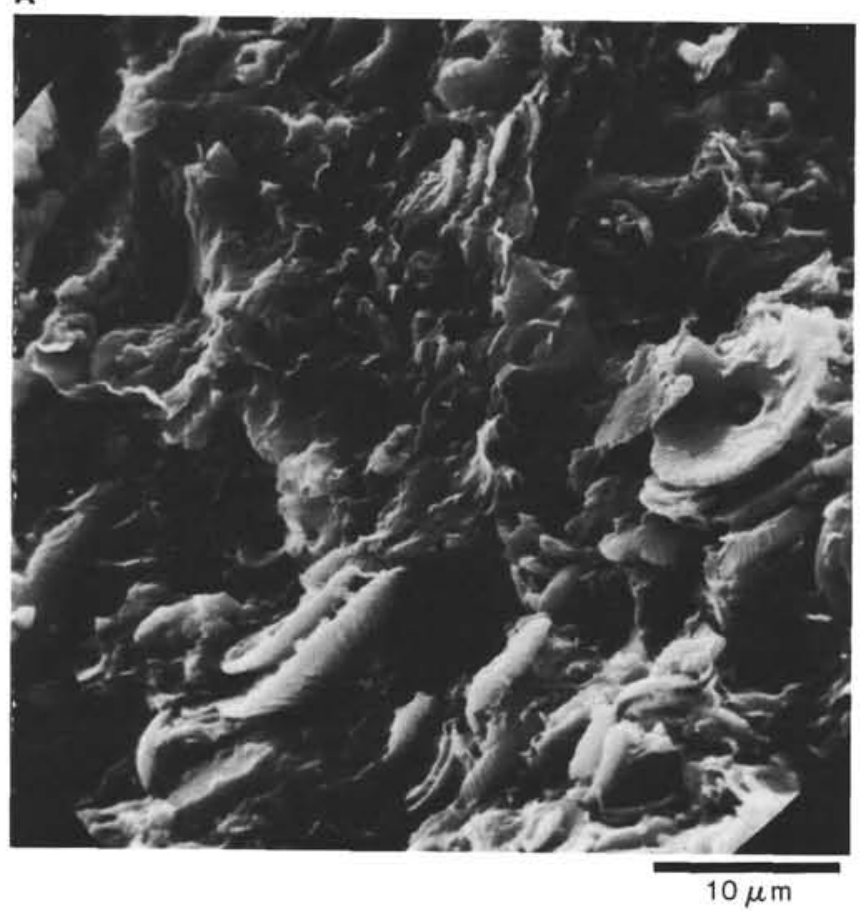

B

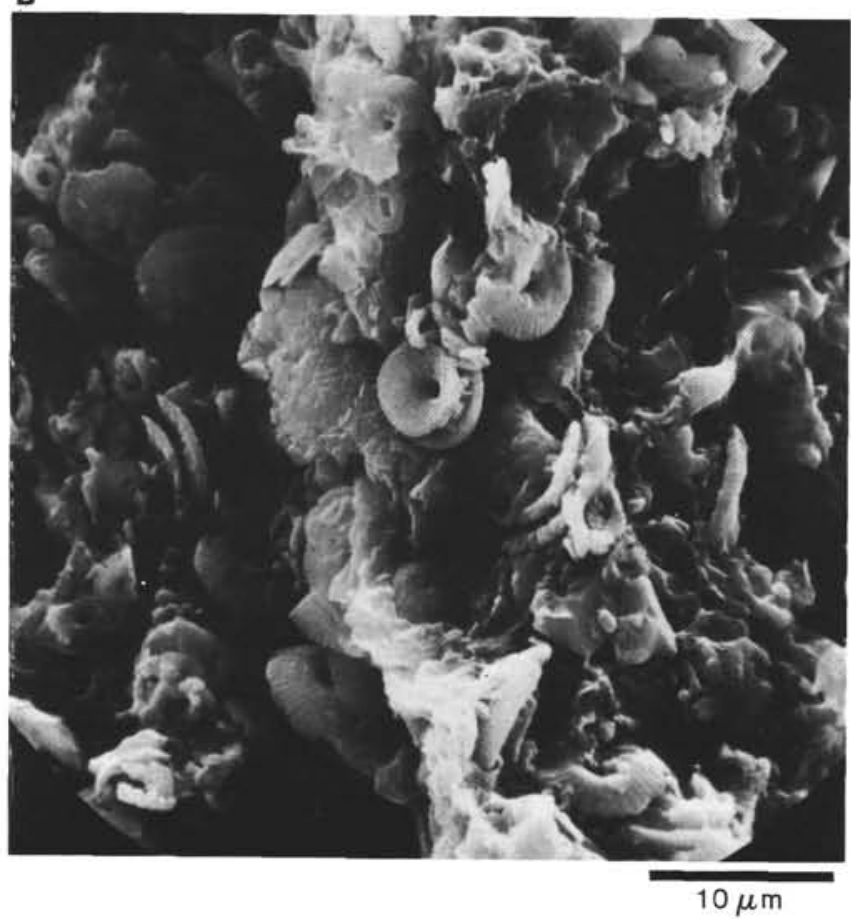

Figure 7. Scanning electron micrographs of two samples of PGLs. A. From Sample $588 \mathrm{C}-13-4,38-40 \mathrm{~cm}$. B. from $588 \mathrm{C}-16-2,74-75 \mathrm{~cm}$. Magnification $\times 2000$.

type (MacEwan, 1972). The asymmetry of the smectite peak on its high-angle side, with superimposed minor peaks between 14 and $10 \AA$, is mainly due to random interstratification of smectite with some illite, and possibly small amounts of other clay species. A consistent set of subdominant peaks at 7.2 and $3.57 \AA$, unaffected by glycolation and acid treatment but destroyed by heating, is caused by kaolinite and not chlorite.

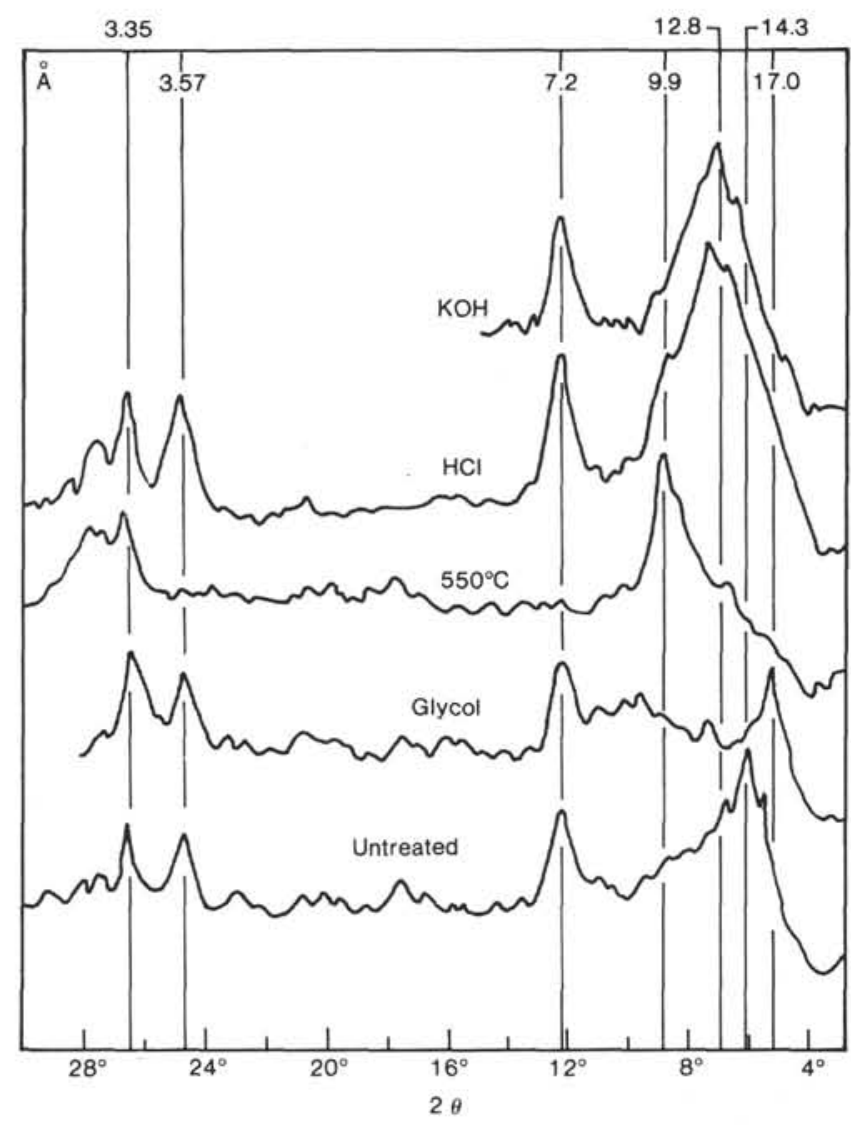

Figure 8. X-ray diffractograms of specially treated PGL samples (see text for a discussion of each of the treatments).

Thus, the detailed clay mineralogy of the $<63-\mu \mathrm{m}$ fraction of the PGLs mainly consists of smectite, with small to moderate amounts of mixed-layer illite-smectite (illite $<$ smectite) and kaolinite. The evidence strongly suggests that the smectites resulted from the argillization of ash material that has settled onto Lord Howe Rise and that the PGLs represent bentonite layers. The presence of some interlayered illite in authigenic volcanogenic smectites is expected (Hein and Scholl, 1978) and is a characteristic feature of K-bentonites (Weaver, 1958; Mossler and Hayes, 1966).

The next piece of evidence suggesting a tephra origin for the PGLs is the common occurrence of concentrations of iron sulfides immediately below a PGL within the surrounding facies (Fig. 2). The iron sulfide layer probably formed as a result of microbial sulfate reduction, a process presently taking place at each of the sites (Baker, this volume). Volcanic ash provides a good reactive source of dissolved iron for combination with the dissolved sulfide. We postulate that the distance of the sulfide layer beneath the PGL, typically $5-10 \mathrm{~cm}$, was approximately the thickness of the oxic zone of bioturbation.

Lastly, Lord Howe Rise is surrounded by regions of active Neogene and Quaternary volcanism, especially explosive rhyolitic and andesitic centers in New Zealand, along the Tonga-Kermadec Arc, the New Hebrides Arc, and the New Britain Arc (Figs. 9 and 10). Ample sources exist for tephra to have been transported to the Tasman 


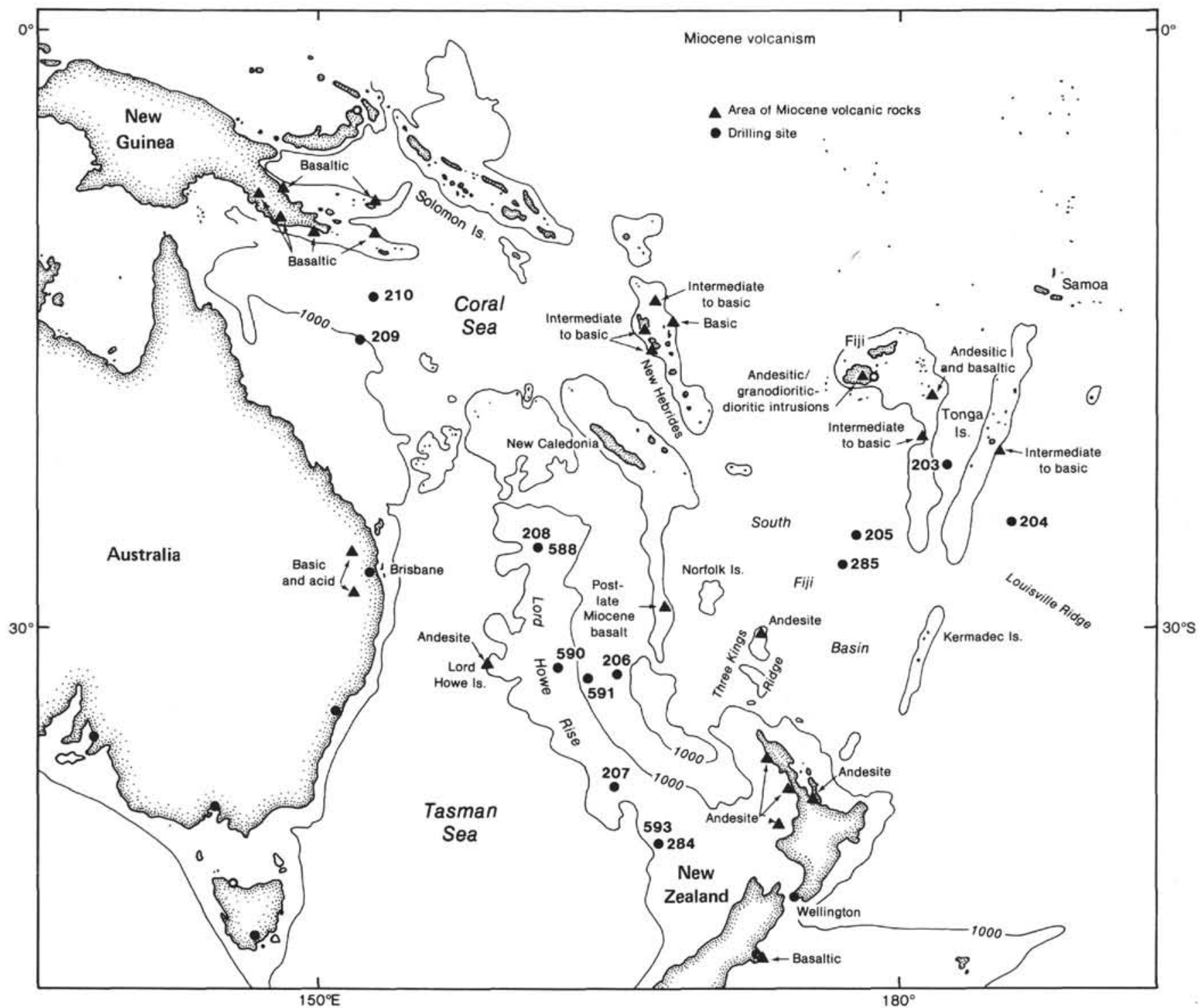

Figure 9. Distribution of known Miocene volcanic rocks in the region of Lord Howe Rise (modified after Churkin and Packham, 1973).

Sea. Explosive volcanoes can produce discrete ash layers in deep-sea sediment several thousand kilometers from the source eruption (Nayudu, 1964; Huang et al., 1973, 1975; Shaw et al., 1974).

\section{DISCUSSION}

One of the most convincing lines of evidence that the PGLs are tephra layers is the correlation of their temporal distribution with the temporal distribution of discrete ash layers in the southwest Pacific and with the global pattern (Fig. 5). Ninkovich and Donn (1976) and Stewart (1975) have cautioned against conclusions about tephrostratigraphy in regions of convergent plate boundaries. Very little relative convergence has occurred between Lord Howe Rise and potential volcanic sources in Australia, New Zealand, and the seamounts within the Tasman Sea. If these regions are the sources for the teph$\mathrm{ra}$, then the tephrostratigraphy is a direct record of volcanism. However, convergence of about $6 \mathrm{~cm} / \mathrm{yr}$. has occurred during the Neogene and Quaternary along the northern boundary between the Pacific and Australian plates at the New Britain and New Hebrides arcs (McDougall et al., 1981). Although northern sources for the volcanic ash are a distinct possibility, the pattern of high abundances of tephra in the middle and early late Miocene and relatively low abundances in the Quaternary is opposite to that expected by convergence alone. However, the Pacific/Australian plate boundary in the vicinity of New Zealand is a potential source for the tephra.

The Pacific/Australian plate boundary in the vicinity of New Zealand formed about $24 \mathrm{~m}$.y. ago, at about the end of the Oligocene (Carter and Norris, 1976; Nelson and Hume, 1977; Sporli, 1980). Island arc volcanism has characterized the boundary during the Neogene and Quaternary (Ballance, 1976; Coleman and Packham, 1976). The tephrostratigraphic record from Lord Howe Rise can be compared with the tectonic nature of the $\mathrm{Pa}$ cific/Australian plate boundary in the southwest Pacific 


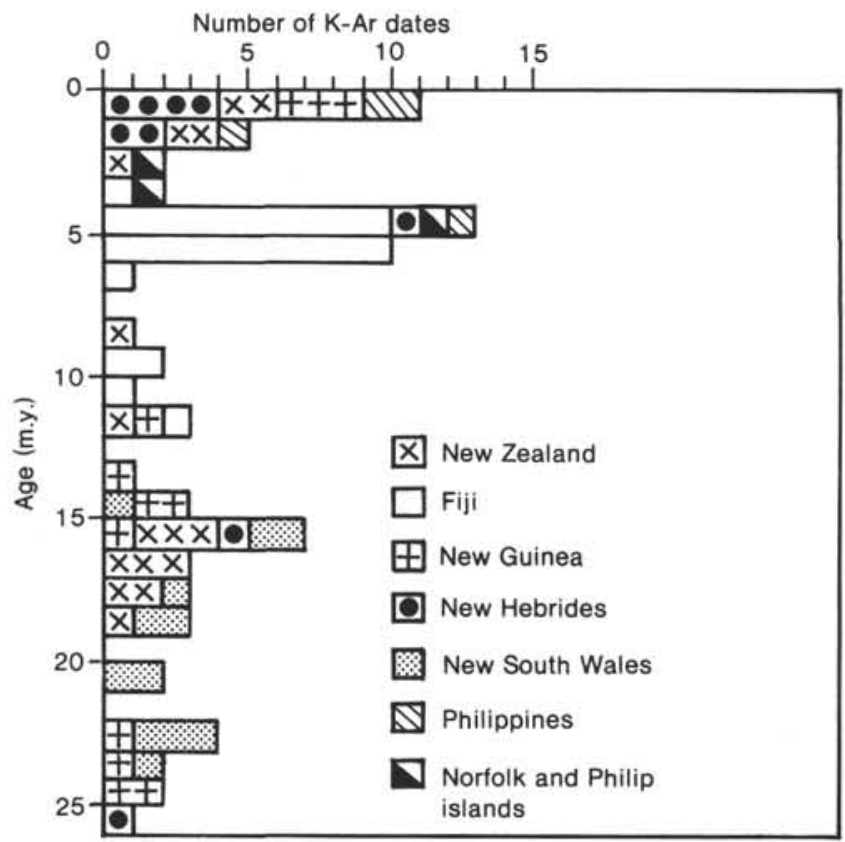

Figure 10. The age, location, and number of K-Ar dates of volcanism in the southwest Pacific for the past 26 m.y. (after Kennett et al., 1977).

over the same period to determine any correlation between volcanism and changes in the rates of seafloor spreading and subduction.

Hodder (in press) used a vectorial approach to analyze tectonism at the Pacific/Australian plate boundary, primarily based on the velocities of plate motions determined from the distribution and age of successive intraplate volcanoes on the two plates. The results of his analysis of boundary convergence velocities at 1-m.y. intervals are shown in Figure 11. Two main periods of relatively accelerated plate convergence are evident in Figure 11, a moderately fast convergence from late early through middle Miocene (20-11 m.y. ago) and a rapidly increased tempo of movement in post-Miocene times (5-0 m.y. ago) that culminated in maximum convergence during the Quaternary. A broad correlation is apparent between these periods of increased intensity of convergent boundary tectonics and the history of Neogene and Quaternary explosive volcanism as interpreted from the PGL record. Two apparent anomalies include the marked period of early late Miocene volcanism (11-8 m.y.) during a time of very slow convergence, and a record of generally sparse volcanism during a period of relatively increased plate movement in the Pliocene (5-2 m.y. ago). Both situations may be partly related to the lag time of volcanism associated with periods of increased tectonic convergence that Hodder (in press) determined can be about $3 \mathrm{~m}$.y. for the northern New Zealand region. Thus, the relatively fast rates of plate motion recorded during late middle Miocene (14-11 m.y. ago) and Pliocene (5-2 m.y. ago) may not have been manifested in the PGL record until the early late Miocene (11-8 m.y. ago) and Quaternary (2-0 m.y. ago), respectively.

Figure 4 shows that tephra from Quaternary volcanism is limited to the sites relatively close to New Zea-

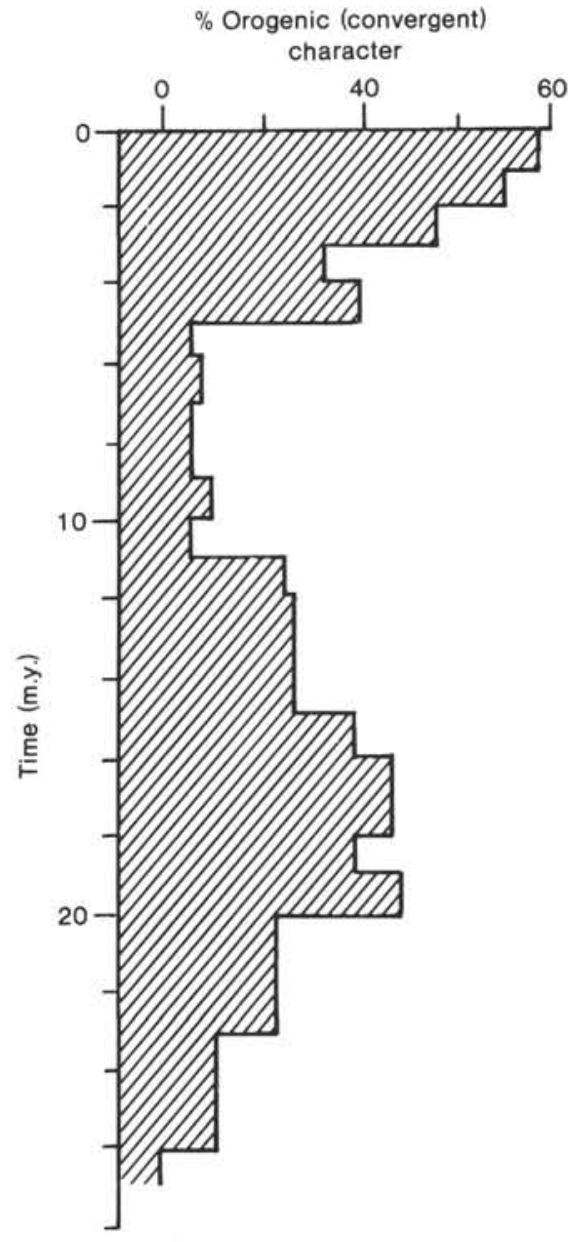

Figure 11. The orogenic convergence of the Pacific/Australian plate boundary in the New Zealand region through the Neogene and Quaternary as it relates to convergent velocity at the boundary (after Hodder, in press). The small negative percentage from 26 to 27 m.y. implies that the boundary was slightly extensional at this time.

land. It is curious that Site 591, the site mentioned earlier that has siliceous biogenic fragments in rare to trace amounts throughout the recovered section, also has numerous bentonites throughout the Quaternary section, whereas nearby Site 590 shows only a few PGLs in the lower Quaternary section. However, Site 590 is a $1299 \mathrm{~m}$ water depth, whereas Site 591 is at $2131 \mathrm{~m}$. It may well be that the Quaternary tephra from the shallower Site 590 has been winnowed out of the sediment or that the bentonites are so subtle as to be indistinguishable to the unaided eye from the surrounding sediment. Nevertheless, Quaternary volcanism in the New Zealand region appears not to have produced as many tephra layers as have episodes of middle and early late Miocene volcanism.

The compilations of Kennett and Thunell (1975) and Kennett et al. (1977) indicate that, on a worldwide basis, Quaternary explosive volcanism was more extensive than middle and early late Miocene volcanism (Fig. 5). However, the numbers of bentonites on Lord Howe Rise suggest that middle and early late Miocene volcanism was much more active in this sector of the southwest Pacific 
than it was during the Quaternary. Middle and early late Miocene explosive volcanism is well documented throughout the southwest Pacific (Mitchell and Warden, 1971; Churkin and Packham, 1973; Kennett and Thunell, 1975; Kennett et al., 1977; Kennett, 1981). The Leg 90 sites on Lord Howe Rise north of New Zealand clearly show a maximum of middle and early late Miocene volcanism, whereas those sites closer to New Zealand do not. This suggests that the tephras from the middle and early late Miocene volcanism came from the island arcs to the north or northeast rather than from New Zealand. An episode of explosive volcanism from island arcs suggests an increase in the rates of subduction or a change in plate motion (Hays et al., 1972) or possibly an increase in global magmatic activity related to deep convective properties (Vogt, 1972). Whatever the cause, the resultant tephra covered northern Lord Howe Rise more frequently than it did the southern area.

There is a curious abundance of PGLs (bentonites) in the lower Miocene section at Site 590 (Fig. 4). Neither the global averages nor the southwest Pacific averages of explosive volcanism show much activity during this time (Fig. 5), although other areas around the Pacific rim do; for example, the Aleutian Arc (Hein and Scholl, 1978). However, the entire Miocene section at both DSDP Site 205 (Burns, Andrews, et al., 1973) and Site 285 (Andrews, Packham, et al., 1975) have facies of predominantly glass shard tuffs. Bentonites in the lower Miocene at Site 590 may have been ashes that originated along the Tonga-Kermadec area, as is suggested by early Miocene fast rates of convergence (Fig. 11). The timing coincides with the first record of voluminous andesitic volcanism in northern New Zealand (Ballance, 1976) that is associated with the propagation of the Pacific/Australian plate boundary through the New Zealand region. Other possible sources include Norfolk Island and Three Kings Ridge (Davey, 1982).

Many upper Oligocene to lower lower Miocene bentonites occur at Site 588 but not at Sites 592 and 593. The distribution of these bentonites at the central region of Lord Howe Rise suggests a northern source of the tephras that displayed relatively minor explosivity. The South Fiji Basin is thought to have been forming during Oligocene time (Watts et al., 1977; Malahoff et al., 1982; Davey, 1982); consequently, this region is a potential source for the tephras. The lower upper Oligocene bentonites appear to have a New Zealand source, but there is only one stratigraphic record (Site 592) that goes that far back in time.

Another curious aspect of the sediment from Lord Howe Rise is the generally low abundances of discrete volcanic glass even in the Quaternary section. Hein and Scholl (1978) and Hein et al. (1978) discussed the diagenesis of tephra and concluded that it generally takes 4 or $5 \mathrm{~m}$.y. to alter ash to bentonites. But, as pointed out earlier, the biosiliceous fossils from Lord Howe Rise have been dissolved even from Quaternary sediment. The cause of the very rapid devitrification of the volcanic ash, as well as the dissolution of biosiliceous material, may well be tied directly to biological processes and water masses (Calvert, 1974). Antarctic Intermediate Water (AAIW) is greatly undersaturated in silica at the Antarctic Divergence (Fig. 12) because of the intense upwelling (Heath, 1974; Calvert, 1974). AAIW is formed at about $60-65^{\circ} \mathrm{S}$ but submerges to about $1000 \mathrm{~m}$ depth by $55^{\circ} \mathrm{S}$. This highly silica-undersaturated water then spreads north, and the first sediment it comes in contact with in the Tasman Sea is on Lord Howe Rise. Any silica within the upper few meters of sediment that was biogenically mixed (Thompson and Wilson, 1980; Weaver and Schultheiss, 1983) should have been subjected to silica dissolution. Although a postdepositional dissolution process such as this appears to have been discounted by Berger (1968) and Bogoyavlenskiy (1967), this mechanism alone could account for the lack of biosiliceous fossils and volcanic glass. Dissolution of silica by AAIW may also explain the presence of biogenic and volcanic silica at Site 591, which is located in $2131 \mathrm{~m}$ water depth, below the direct influence of AAIW. Consequently, severe silica dissolution may not be as prevalent at Site 591 as at the other Leg 90 sites on Lord Howe Rise.

If the PGLs in Leg 90 sediment do indeed correspond to diagenetically altered volcanic ash layers, then whether or not they are identified will significantly affect the interpretation of the frequency of volcanic activity in the region. For example, our data are derived from five sites drilled on Lord Howe Rise with the hydraulic piston corer (HPC) and extended core barrel (XCB). Kennett and Thunell (1975) considered four sites that were rotary drilled on Lord Howe Rise in their global compilation of volcanic ash layers in deep-sea sediment. They recorded no volcanic ash layers in two sites and only multiple ash layers in the Quaternary sections of the other two sites. Compare their observations of an apparently very simple volcanic history with the complexity of our Neogene and Quaternary tephrostratigraphies in Figure 4 . The difference partly reflects the far better quality of the Leg 90 cores, as well as the recognition that PGLs represent altered ash layers. If, in fact, we had counted only the number of truly megascopic, glass-rich ash layers and pods in the Leg 90 sediments, then we would have recorded a total of only 11 volcanic episodes, seven of Quaternary age and two each from lower and upper Miocene sequences (Nelson et al., this volume).

\section{CONCLUSIONS}

Pale green laminae that occur conspicuously in sediment from Lord Howe Rise reflect episodes of volcanism from sources in the southwest Pacific. The evidence that leads to this interpretation includes the following: (1) The timing of the occurrences of the laminae matches the periods of known volcanism from the circum-Pacific and the southwest Pacific. (2) There is a general correspondence between the occurrence of laminae and the presence of volcanic glass in smear slides. (3) The flow of corrosive Antarctic Intermediate Water in contact with the surface of Lord Howe Rise, depleted in silica at its source region at the Antarctic Divergence, accounts for the lack of both biogenic and volcanic silica in the sediments of Lord Howe Rise. (4) The pale green laminae generally occur in association with iron sulfide. The iron necessary for the formation of the iron sulfides proba- 


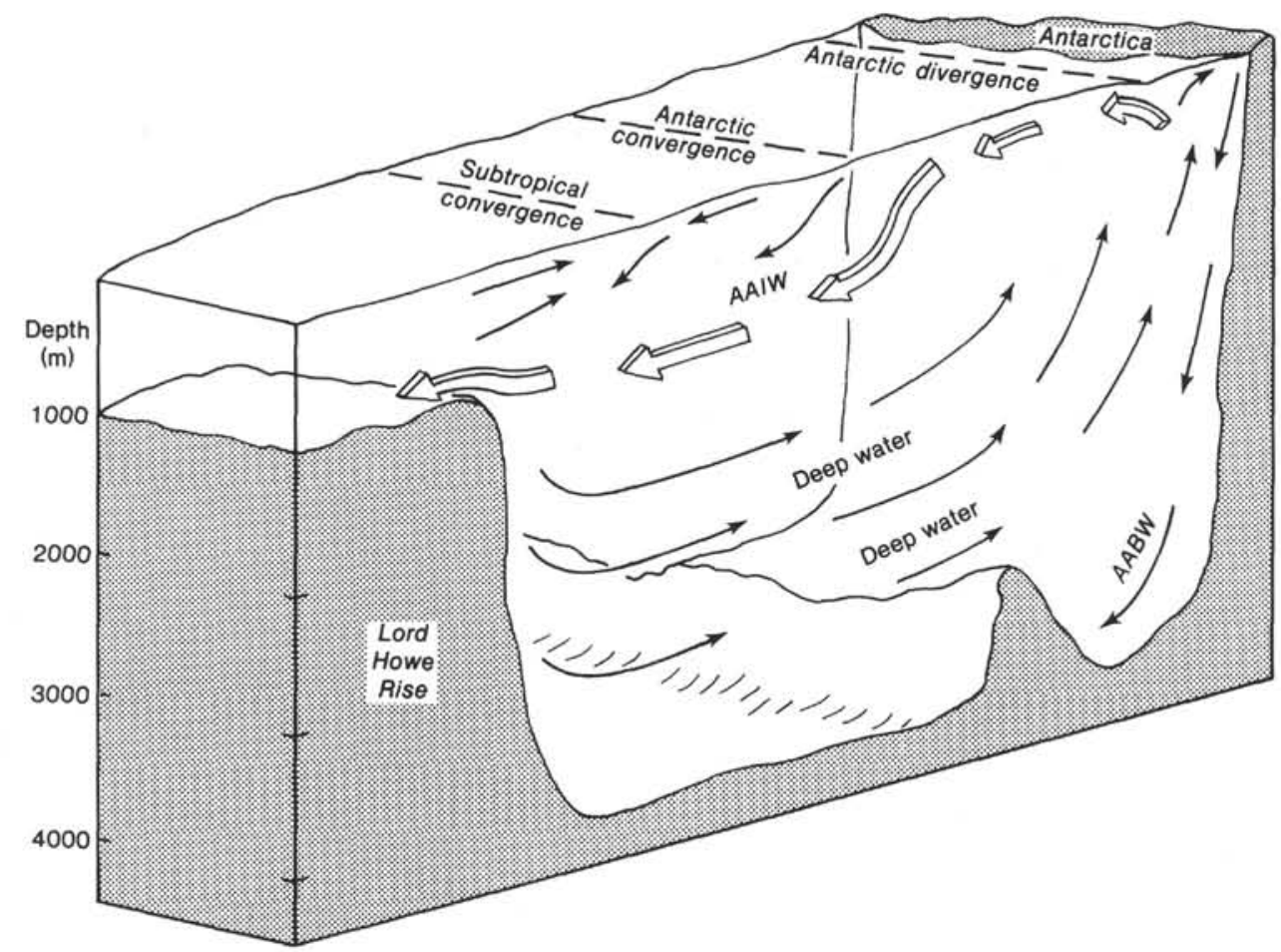

Figure 12. The generalized circulation of subsurface water masses in the southwest Pacific, showing the relationship between Antarctic Intermediate Water (AAIW) and the topographic expression of Lord Howe Rise (modified after Knox, 1970).

bly was supplied by the alteration of the overlying volcanic ash, and the sulfur was supplied by sulfate reduction occurring within pore water. (5) Clay mineralogy of the PGLs indicates that authigenic smectite is dominant over other clay minerals. High contents of smectite where the smectite contains only few crystallographically intermixed illite layers is considered to be derived from the alteration of volcanic ash. (6) Lord Howe Rise is surrounded by regions of active Neogene and Quaternary volcanism; consequently, volcanic ash is an expected component of the sediment.

Despite the reasonably good correlation between our composite PGL stratigraphy and the changes in intensity of plate motions at the Pacific/Australian plate boundary, lending support to Kennett et al.'s (1977) interpretation of synchronous episodes of especially intense volcanism in the circum-Pacific region in the middle and early late Miocene and in the Quaternary, it is clear that the record at individual Leg 90 sites does not necessarily follow the general trend. More refined interpretations concerning the significance of the PGL stratigraphy is presently hampered by the lack of information on the specific source areas of the ashes. Potential sources include not only the major New Zealand, Tonga-Kermadec, and Melanesian calc-alkaline volcanic arcs at the Pacific/Australian plate boundary (Ballance, 1976; Coleman and Packham, 1976), but also the central volcanoes of eastern Australia (Wellman and McDougall, 1974), the chains of volcanic seamounts in western Tasman Sea (McDougall et al., 1981), and the back-arc basins of east- ern Tasman Sea and Coral Sea (Karig, 1971; Malahoff et al., 1982). The pervasive diagenesis of the PGLs poses a challenging geochemical and mineralogical analytical problem if they are to be ultimately fingerprinted as to source.

\section{ACKNOWLEDGMENTS}

We thank A. P. W. Hodder, University of Waikato, for access to unpublished information on the convergence of the Pacific and Australian plates and C. K. Beltz, University of Waikato, for SEM assistance. Eileen Hemphill, U.S. Geological Survey, analyzed many of the samples for clay mineralogy, and our thanks go to J. R. Hein for allowing her the use of his XRD. We thank the staff of the West Coast DSDP Repository for their help in resampling some cores. We appreciate the constructive reviews by W. E. Dean, J. R. Hein, and T. L. Vallier. This work was supported, in part, by the U.S.G.S. Climate Program.

\section{REFERENCES}

Andrews, J. E., Packham, G., et al., 1975. Init. Repts. DSDP, 30: Washington (U.S. Govt. Printing Office).

Arrhenius, G., 1963. Pelagic sediments. In Hill, M. N. (Ed.), The Sea (Vol. 3): New York (Interscience Publ.), pp. 655-727.

Arthur, M. A., Dean, W. E., Bottjer, D., and Scholle, P. A., in press. Rhythmic bedding in Mesozoic-Cenozoic pelagic carbonate sequences: the primary and diagenetic origin of Milankovitch-like cycles. In Berger, A., Imbrie, J., and Hays. J. D. (Eds.), Milankovitch and Climate: NATO Advanced Workshop Series. (Riedel Publ. Co.).

Ballance, P. F., 1976. Evolution of the upper Cenozoic magmatic arc and plate boundary in northern New Zealand. Earth Planet Sci. Lett., 28:356-370.

Berger, W. H., 1968. Radiolarian skeletons: solution at depths. Science, 159:1237-1238. 
Biscaye, P. E., 1965. Mineralogy and sedimentation of Recent deepsea clay in the Atlantic Ocean and adjacent seas and oceans. Geol. Soc. Am. Bull., 76:803-832.

Bogoyavlenskiy, A. N., 1967. Distribution and migration of dissolved silica in oceans. Intl. Geol. Rev., 9:133-153.

Bonatti, E., 1972. Authigenesis of minerals-marine. In Fairbridge, R. W. (Ed.), Encyclopedia of Geochemistry and Environmental Sciences: New York (Van Nostrand Reinhold Co.), pp. 48-56.

Brindley, G. W., 1972. Chlorite minerals. In Brown, G. (Ed.), X-ray Identification and Crystal Structures of Clay Minerals. London (Mineralogical Soc.) pp. 242-296.

Burns, R. E., Andrews, J. E., et al., 1973. Init. Repts. DSDP, 21: Washington (U.S. Govt. Printing Office).

Calvert, S. E., 1974. Deposition and diagenesis of silica in marine sediments. In Hsü, K. J., and Jenkyns, H. C. (Eds.), Pelagic Sediments: On Land and Under the Sea. Intl. Assoc. Sedimentol. Spec. Publ. 1, pp. 273-299.

Carroll, D. and Starkey, H. C., 1971. Reactivity of clay minerals with acids and alkalies. Clays Clay Min. 19:321-335.

Carter, R. M., and Norris, R. J., 1976. Cainozoic history of southern New Zealand: an accord between geological observations and plate tectonic predictions. Earth Planet. Sci. Lett., 31:85-94.

Churkin, M., Jr., and Packham, G. H., 1973. Volcanic rocks and volcanic constituents in sediments, Leg 21, Deep Sea Drilling Project. In Burns, R. E., Andrews, J. E., et al., Init. Repts. DSDP, 21: Washington (U.S. Govt. Printing Office), 481-493.

Coleman, P. J., and Packham, G. H., 1976. The Melanesian borderlands and India-Pacific plates' boundary. Earth Sci. Rev., 12: 197-233.

Davey, F. J., 1982. The structure of the South Fiji Basin. Tectonophysics, 87:185-241.

Dean W. E., Gardner, J. V., and Čepek, P., 1981. Tertiary carbonatedissolution cycles on the Sierra Leone Rise, eastern equatorial Atlantic Ocean. Mar. Geol., 39:81-101.

Dean, W. E., Gardner, J. V., Jansa, L. F., Čepek, P., and Seibold, E., 1977. Cyclic sedimentation along the continental margin of northwest Africa. In Lancelot, Y., Seibold, E., et al., Init. Repts. DSDP, 41: Washington (U.S. Govt. Printing Office), 965-986.

de Vries, T. J., and Schrader, H. J., 1981. Variation of upwelling/oceanic conditions during the latest Pleistocene through Holocene off the central Peruvian coast: A diatom record. Mar. Micropaleontol., 6:57:-167.

Diester-Haass, L., and Schrader, H. J., 1979. Neogene coastal upwelling history off northwest and southwest Africa. Mar. Geol., 29: 39-53.

Gardner, J. V., 1975. Late Pleistocene carbonate dissolution cycles in the eastern equatorial Atlantic. In Sliter, W. V., Bé, A. W. H., and Berger, W. H., (Eds.), Dissolution of Deep-Sea Carbonates. Cushman Foundation Foram. Res., Spec. Publ. 13, pp. 129-141.

Hathaway, J. C., and Sachs, P. L., 1965. Sepiolite and clinoptilolite from the Mid-Atlantic Ridge. Am. Mineralogist., 50:852-867.

Hays, J. D. Cook, H. E., Jenkins, G., Orr, W., Goll, R., Cook, F., Milow, D., and Fuller, J., 1972. An interpretation of the geologic history of the eastern equatorial Pacific from the drilling results of Glomar Challenger, Leg 9. In Hays, J. D., et al., Init. Repts. DSDP, 9: Washington (U.S. Govt. Printing Office), 909-931.

Heath, G. R., 1974. Dissolved silica and deep-sea sediments. In Hay, W. W. (Ed.), Studies in Paleo-oceanography. Soc. Econ. Paleontol. Mineral. Spec. Publ. 20, pp. 77-93.

Hein, J. R., and Scholl, D. W., 1978. Diagenesis and distribution of late Cenozoic volcanic sediment in the southern Bering Sea. Geol. Soc. Am. Bull., 89:197-210.

Hein, J. R., Scholl, D. W., and Gutmacher, C. E., 1976. Neogene clay minerals of the far NW Pacific and southern Bering Sea: Sedimentation and diagenesis. In Bailey, S. W. (Ed.), AIPEA Proceedings, International Clay Conf. Mexico City, 1975: Wilmette, Ill. (Aied Publishing Ltd.), pp. 71-80.

Hein, J. R., Scholl, D. W., and Miller, J., 1978. Episodes of Aleutian Ridge explosive volcanism. Science, 199:137-141.

Hodder, A. P. W., in press. Neogene tectonic intensity at the Australian-Pacific plate boundary at New Guinea and New Zealand; A vectorial approach. J. Geol. Soc. Australia.
Huang, T. C., Watkins, N. D., and Shaw, D. M., 1975. Atmospherically transported volcanic glass in deep-sea sediment: volcanism in sub-Antarctic latitudes of the South Pacific during late Pliocene and Pleistocene time. Geol. Soc. Am. Bull., 86:1305-1315.

Huang, T. C., Watkins, N. D., Shaw, D. M., and Kennett, J. P., 1973. Atmospherically transported volcanic dust in South Pacific deep sea sediment cores at distances over $3000 \mathrm{~km}$ from the eruptive source. Earth Planet. Sci. Lett., 20:119-124.

Hume, T. M., and Nelson, C. S., 1982. X-ray diffraction analytical procedure and some mineralogical characteristics for South Auckland region sediments and sedimentary rocks, with special reference to their clay fraction. Occasional Rept. 10, Univ. Waikato.

Karig, D. E., 1971. Origin and development of marginal basins in the Western Pacific. J. Geophys. Res., 76:2542-2561.

Kennett, J. P., 1981. Marine tephrochronology. In Emiliani, C. (Ed.), The Sea (Vol. 7): New York (John Wiley), pp. 1373-1436.

Kennett, J. P., McBirney, A. R., and Thunell, R. C., 1977. Episodes of Cenozoic volcanism in the circum-Pacific region. J. Volc. Geotherm. Res., 2:145-163.

Kennett, J. P., and Thunell, R. C., 1975. Global increase in Quaternary explosive volcanism. Science, 187:497-503.

Knox, G. A., 1970. Biological oceanography of the South Pacific. In Wooster, W. S. (Ed.), Scientific Exploration of the South Pacific: Washington (National Academy of Sciences), pp. 155-182.

Ledbetter, M. T., 1982. Tephrochronology at Sites 502 and 503. In Prell, W. L., Gardner, J. V., et al., Init. Repts. DSDP, 68: Washington (U.S. Govt. Printing Office), 403-408.

McDougall, E., Embleton, B. J. J., and Stone, D. B., 1981. Origin and evolution of Lord Howe Island, southwest Pacific Ocean. $J$. Geol. Soc. Australia, 28:155-176.

MacEwan, D. M. C., 1972. Montmorillonite minerals. In Brown, G. (Ed.), X-ray Identification and Crystal Structures of Clay Minerals. London (Mineralogical Soc.), pp. 143-207.

Malahoff, A., Feden, R. H., and Fleming, H. S., 1982. Magnetic anomalies and tectonic fabric of marginal basins north of New Zealand. J. Geophys. Res., 87:4109-4125.

Mitchell, A. H. G., and Warden, A. J., 1971. Geological evolution of the New Hebrides island arc. J. Geol. Soc. London, 127:501-529.

Mossler, J. M., Hayes, J. B., 1966. Ordovician K-bentonites of Iowa. J. Sed. Petrol., 36:414-424.

Nayudu, Y. R., 1964. Palgonite tuffs (hyaloclastites) and the products of posteruptive processes. Bull. Volcanolog., 27:332-341.

Nelson, C. S., and Hume, T. M., 1977. Relative intensity of tectonic events revealed by the Tertiary sedimentary record in the North Wanganui basin and adjacent areas, New Zealand. N.Z. J. Geol. Geophys., 20:369-392.

Ninkovich, D., and Donn, W. L., 1976. Explosive Cenozoic volcanism and climatic implications. Science, 194:899-906.

Peterson, M. N. A., and Griffin, J. J., 1964. Volcanism and clay minerals in the southeastern Pacific. J. Mar. Res., 22:287-312.

Schuette, G., and Schrader, J. J., 1981. Diatom taphocoenoses in the coastal upwelling area off southwest Africa. Mar. Micropaleontol., 6:131-155.

Shaw, D. M., Watkins, N. D., and Huang, T. C., 1974. Atmospherically transported volcanic glass in deep-sea sediment: theroretical calculations. J. Geophys. Res., 79:3087-3094.

Siever, R., and Kastner, M., 1967. Mineralogy and petrology of some Mid-Atlantic Ridge sediments. Mar. Res., 25:263-278.

Sporli, K. B., 1980. New Zealand and oblique-slip margins: tectonic development up to and during the Cainozoic. Spec. Publ. Internat. Assoc. Sedimentol., 4:147-170.

Stewart, R. J., 1975. Late Cainozoic explosive eruptions in the Aleutian and Kuril island arcs. Nature, 258:505-507.

Stonecipher, S. A., 1974. Distribution of zeolites in marine sediments, Geol. Soc. Am. Abstr. with Progr. 6:262-263. (Abstract)

Thompson, J., and Wilson, T. R. S., 1980. Burrow-like structures at depth in a Cape Basin red clay core. Deep-Sea Res., 27A:97-202.

Vogt, P. R., 1972. Evidence for global synchronism in mantle plume convection, and possible significance for geology. Nature, 240: 87-118.

von Rad, U., and Rösch, H., 1972. Mineralogy and origin of clay minerals, silica and authigenic silicates in Leg 14 sediments. In Hayes, 
D. E., Pimm, A. C., et al., Init. Repts. DSDP, 14: Washington (U.S. Govt. Printing Office), 727-751.

Watts, A. B., Weissel, J. K., and Davey, F. J., 1977. Tectonic evolution of South Fiji marginal basins. In Talwani, M., and Pittman, W. C. (Eds.), Island Arcs Deep-Sea Trenches, and Back-arc Basins. Am. Geophys. Un. Maurice Ewing Ser. 1:419-427.

Weaver, C. E., 1958. The effects and geological significance of potassium "fixation" by expandable clay minerals derived from muscovite, biotite, chlorite and volcanic material. Am. Mineralogist, 43: 839-861.
Weaver, P. P. E., and Schultheiss, P. J., 1983. Vertical open burrows in deep-sea sediments $2 \mathrm{~m}$ in length. Nature, 301:329-331.

Wellman, P., McDougall, I., 1974. Cainozoic igneous activity in eastern Australia. Tectonophysics, 23:49-65.

Wilson, M. D., and Pittman, E. D., 1977. Authigenic clays in sandstones: Recognition and influence on reservoir properties and paleoenvironmental analysis. J. Sed. Petrol., 47:3-31.

Date of Initial Receipt: 11 May 1984 Date of Acceptance: 3 August 1984 